\title{
Pengaruh substitusi pupuk anorganik dengan pupuk herbal organik terhadap pertumbuhan dan produksi tanaman tomat (Lycopersicum esculentum mill) varietas permata
}

\author{
(Response of subtitution inorganic fertilizer with herbs organic fertilizer on growth and \\ production of tomato plant (Lycopersicum esculentum mill) permata varieties) \\ R. D. Sari, S. Budiyanto, dan Sumarsono \\ Agricultural Department, Faculty of Animal and Agricultural Sciences, Diponegoro University \\ Tembalang Campus, Semarang 50275 - Indonesia \\ CorrespondingE-mail :rifaya_dani@yahoo.com
}

\begin{abstract}
The aim of this research was to observe of subtitution of inorganic fertilizer with organic herbs fertilizer on growth and production of tomato plants. The research used Monofactor Completely Randomized Design with 3 replications. The treatment that substitution of inorganic fertilizer with organic herbal fertilizer were $100 \%+0 \%\left(\mathrm{~T}_{0}\right) ; 80 \%+20 \%\left(\mathrm{~T}_{1}\right) ; 60 \%+40 \%\left(\mathrm{~T}_{2}\right) ;\left(\mathrm{T}_{3}\right) 40 \%+60 \%\left(\mathrm{~T}_{3}\right) ; 20 \%$ $+80 \%\left(\mathrm{~T}_{4}\right) ; 0 \%+100 \%\left(\mathrm{~T}_{5}\right)$. Parameters observed were plant height, number of leaves, number of flowers, number of fruit and weight of fresh fruit. Data were analysis of variabel (F Test) and further test with Tukey Multiple Range Test (BNT). The results showed that the substitution of fertilizer on treatment $\mathrm{T} 3$ ( $40 \%$ of inorganic fertilizers $+60 \%$ organic herbal fertilizer) can give number of leaves, number of flowers, number of fruit and weight of fresh fruit higher than compared with the other treatment. However, no significant effect on plant height.
\end{abstract}

Keywords: Tomato varieties of permata, organic herbal fertilizer, dosage

\begin{abstract}
ABSTRAK
Penelitian bertujuan untuk mengetahui pengaruh substitusi pupuk anorganik dengan pupuk herbal organik terhadap pertumbuhan dan produksi tanaman tomat. Penelitian menggunakan percobaan Monofaktor Rancangan Acak Lengkap dengan 3 ulangan. Perlakuan yang diberikan adalah substitusi pupuk anorganik dengan pupuk herbal organik yaitu $100 \%+0 \%\left(\mathrm{~T}_{0}\right) ; 80 \%+20 \%\left(\mathrm{~T}_{1}\right) ; 60 \%+40 \%\left(\mathrm{~T}_{2}\right)$; $\left(\mathrm{T}_{3}\right) 40 \%+60 \%\left(\mathrm{~T}_{3}\right) ; 20 \%+80 \%\left(\mathrm{~T}_{4}\right) ; 0 \%+100 \%\left(\mathrm{~T}_{5}\right)$. Parameter yang diamati yaitu tinggi tanaman, jumlah daun, jumlah bunga, jumlah buah dan berat buah segar. Data diolah dengan analisis ragam (Uji F) dan uji lanjut dengan Beda Nyata Terkecil (BNT). Hasil penelitian menunjukkan bahwa substitusi pupuk pada perlakuan T3 (40\% pupuk anorganik $+60 \%$ pupuk herbal organik) dapat menghasilkan jumlah daun, jumlah bunga, jumlah buah dan berat segar buah tomat lebih tinggi dibandingkan dengan perlakuan lainnya. Namun tidak berpengaruh nyata terhadap tinggi tanaman.

Kata kunci: tomat varietas permata, pupuk herbal organik, dosis
\end{abstract}

\section{PENDAHULUAN}

Tomat merupakan salah satu jenis sayuran buah yang mempunyai prospek yang baik dalam pengembangan agribisnis, karena nilai gizi dan ekonominya tinggi (Bernadus dan Wahyu, 2002). Buah tomat mengandung vitamin $\mathrm{C}$ sehingga sangat baik untuk mencegah dan mengobati penyakit, seperti sariawan. Tomat selain dikonsumsi sebagai buah segar, dapat juga digunakan sebagai bahan penyedap dan bahan industri makanan dan minuman (Heriani et al., 2013).

Petani di Indonesia sebagian besar masih 
mengunakan cara bercocok tanam yang dilakukan konvensional terutama dalam penggunaan pupuk yang hanya menggunakan pupuk buatan NPK saja (Haerul et al., 2015). Rendahnya produksi tanaman tomat di Indonesia, penyebabnya adalah penurunan kualitas lahan pertanian yang mengakibatkan menurunnya kesuburan lahan yang berdampak pada fisik tanah yaitu kandungan $\mathrm{C}$ Organik semakin berkurang, terkurasnya unsur mikro dalam tanah, dan berkurangnya aktivitas mikroorganisme tanah. Hal ini dikhawatirkan dalam jangka panjang dapat merusak sifat fisik, kimia, dan biologi tanah (Wahyunindyawati et al., 2012). Masalah ini menimbulkan kesadaran petani akan pentingnya pertanian organik dan berkelanjutan yang mampu mendorong meningkatnya penggunaan pupuk organik. Pupuk organik dapat menjadi salah satu alternatif yang tepat dalam mengatasi permasalahan tersebut karena fungsinya yang dapat memberikan tambahan bahan organik, hara, memperbaiki sifat fisik tanah, serta mengembalikan hara yang terangkut oleh hasil panen (Leovini, 2012).

Pupuk herbal organik adalah pupuk bio organik yang diproduksi dari hasil samping produk jamu yang berbahan baku tanaman obat dan rempah-rempah (Syofia et al., 2015). Pupuk herbal organik adalah pupuk organik yang mengandung bioprotektant yang memiliki kandungan $\mathrm{C}$-organik, mikroorganisme, bakteri selulotik, asam humat, asam fulfat dan hormon tanaman. Hormon tanaman sangat berperan dalam pemacu pertumbuhan dan perkembangan tanaman. Pupuk organik yang mengandung mikroorganisme tanah bermanfaat sebagai dekomposer (pengurai) dan penyedia nutrisi dari alam. Kelebihan pupuk herbal organik dibanding pupuk organik lainnya yaitu mengurangi dosis pupuk kimia seperti pupuk NPK hingga 50\% secara bertahap (Hayani et al., 2013).

Upaya yang dilakukan untuk meningkatkan kualitas lahan pertanian produktivitas tomat, yaitu dengan menggunakan pupuk organik yang dikombinasikan dengan pupuk anorganik. Keuntungan dari penggunaan pupuk organik dapat meningkatkan kualitas maupun kuantitas hasil tanaman serta mampu mengurangi penggunaan pupuk anorganik (Rehatta et al., 2014). Kombinasi pupuk organik dan pupuk anorganik sebagai salah satu inovasi yang diharapkan mampu untuk mengatasi permasalahan pertanian konvensional yang perlahan akan maju ke pertanian organik dengan tujuan untuk mendapatkan kombinasi pupuk yang tepat sehingga mampu memberikan pertumbuhan dan hasil produksi terbaik pada tanaman tomat.

Penelitian ini bertujuan untuk mengetahui pengaruh pemberian pupuk herbal organik dengan dosis yang berbeda-beda terhadap peningkatkan pertumbuhan dan produksi tanaman tomat.

\section{MATERI DAN METODE}

\section{Materi Penelitian}

Penelitian dilaksanakan pada April 2017 Juli 2017 di Lahan Warga Jl. Nirwanasari Raya, Tembalang, Semarang. Analisis tanah dan hasil panen tanaman telah dilaksanakan pada bulan Agustus 2017 di Laboratorium Ekologi dan Produksi Tanaman, Fakultas Peternakan dan Pertanian, Universitas Diponegoro, Semarang. Alat yang digunakan dalam penelitian ini adalah screenhouse ( $4 \mathrm{~m} \times 3 \mathrm{~m})$, polybag, cangkul, sekop, timbangan analitik, timbangan, gembor, sprayer, meteran, net, tali rafia, gunting, kamera dan alat tulis. Bahan yang digunakan antara lain benih tomat varietas permata $\mathrm{F} 1$, pupuk herbal organik, pupuk urea (45\%), pupuk TSP (48\%), pupuk $\mathrm{KCl}$ $(60 \%)$ dan air.

\section{Metode Penelitian}

Penelitian dilakukan menggunakan percobaan Monofaktor Rancangan Acak Lengkap dengan 3 kali ulangan. Perlakuan yang diberikan yaitu substitusi pupuk anorganik dengan pupuk herbal organik (pupuk anorganik + pupuk herbal organik). sebanyak 6 tingkat, yaitu $100 \%+0 \%$ $\left(\mathrm{T}_{0}\right) ; 80 \%+20 \%\left(\mathrm{~T}_{1}\right) ; 60 \%+40 \%\left(\mathrm{~T}_{2}\right) ; 40 \%+60 \%$ $\left(\mathrm{T}_{3}\right) ; 20 \%+80 \%\left(\mathrm{~T}_{4}\right) ; 0 \%+100 \%\left(\mathrm{~T}_{5}\right)$.

Penelitian ini dimulai dari analisis tanah untuk mengetahui kandungan $\mathrm{N}, \mathrm{P}, \mathrm{K}$, dan $\mathrm{pH}$ tanah. Persiapan penanaman dilakukan dengan penyemaian benih tomat varietas permata dan pengambilan tanah kemudian dimasukkan ke dalam polybag. Tanah dianalisis kandungan N, P, $\mathrm{K}$, dan $\mathrm{C}$ di Laboratorium Ekologi dan Produksi Tanaman Universitas Diponegoro, Semarang.

Penanaman dilakukan setelah bibit tomat berumur 3 minggu dan pemupukan pertama dilakukan pada 1 hari setelah tanam (HST) 
menggunakan pupuk herbal organik $1 / 3$ dan pupuk NPK di berikan 8 HST setelah pemberian pupuk herbal organik sebanyak $2 / 3 \mathrm{~N}, 1 / 3 \mathrm{P}$, dan $1 / 3 \mathrm{~K}$. Pemupukan kedua dilakukan pada 31 hari setelah tanam (HST) menggunakan pupuk herbal organik $2 / 3$ dan pupuk NPK di berikan 38 HST setelah pemberian pupuk herbal organik sebanyak $1 / 3 \mathrm{~N}$, $2 / 3$ P, dan $2 / 3$ K. Pengamatan tinggi dilakukan dari 1 HST sampai 85 HST. Pemanenan dilakukan pada 88-97 HST dengan memilih buah yang berwarna jingga hingga kemerahan dan ditimbang berat segarnya. Parameter pertumbuhan yang diamati yaitu tinggi tanaman, jumlah daun dan parameter produksi yang diamati yaitu jumlah bunga, jumlah buah, dan berat buah segar.

Analisis data dilakukan dengan menggunakan analisis ragam (Uji $\mathrm{F})$ dan dilanjutkan dengan Uji Beda Nyata Terkecil (BNT).

\section{HASIL DAN PEMBAHASAN}

\section{Tinggi Tanaman}

Hasil analisis ragam menunjukkan bahwa perlakuan substitusi pupuk anorganik dengan pupuk herbal organik tidak berpengaruh nyata terhadap tinggi tanaman tomat. Hasil penelitian pengaruh substitusi pupuk anorganik dengan pupuk herbal organik disajikan pada Tabel 1 .

Tabel 1 memperlihatkan bahwa perlakuan substitusi pupuk anorganik dengan pupuk organik tidak menunjukkan perbedaan yang nyata terhadap tinggi tanaman. Hal ini diduga bahwa pupuk organik yang tidak cepat larut dan pupuk anorganik yang mudah larut walaupun ketersediaan unsur hara yang dibutuhkan tanaman berbeda ternyata mempengaruhi tinggi tanaman atau dalam kata lain perlakuan yang dicobakan memiliki tinggi tanaman yang sama (Sutoyo dan Hulopi, 2009). Ketersediaan nitrogen didalam kedua pupuk tersebut berfungsi dalam pertumbuhan tanaman. Agustina (2004) menambahkan fungsi nitrogen untuk pertumbuhan tanaman dan juga sebagai komponen enzim serta protein yang berperan penting dalam metabolisme tanaman.

Urea dan pupuk herbal organik mengandung berbagai macam unsur hara yang memiliki peranan penting dalam tinggi tanaman. Menurut Syaifuddin et al. (2013) urea merupakan sumber pupuk nitrogen yang esensial menunjang produktivitas tanaman karena kandungan nitrogen yang tinggi. Nasrun et al. (2014) menambahkan bahwa pemberian bio organik herbafarm mengandung hormon tanaman dan beberapa mikroba fertilizer yang mampu merangsang pertumbuhan tinggi tanaman.

\section{Jumlah Daun}

Hasil analisis ragam menunjukkan bahwa perlakuan substitusi pupuk anorganik dengan pupuk herbal organik berpengaruh nyata $(\mathrm{P}<0,05)$ terhadap jumlah daun tanaman tomat. Jumlah daun pada berbagai perlakuan substitusi pupuk anorganik dengan pupuk herbal organik disajikan pada Tabel 2.

Hasil uji lanjut dengan BNT menunjukkan bahwa jumlah daun pada semua perlakuan

Tabel 1. Rerata tinggi tanaman tomat pada berbagai perlakuan substitusi

\begin{tabular}{cc}
\hline \hline Perlakuan & Tinggi Tanaman \\
\hline & $----c m---$ \\
$\mathrm{T}_{0}(0 \%$ pupuk herbal organik $+100 \%$ urea $)$ & 165,3 \\
$\mathrm{~T}_{1}(20 \%$ pupuk herbal organik $+80 \%$ urea $)$ & 154,0 \\
$\mathrm{~T}_{2}(40 \%$ pupuk herbal organik $+60 \%$ urea $)$ & 184,7 \\
$\mathrm{~T}_{3}(60 \%$ pupuk herbal organik $+40 \%$ urea $)$ & 185,0 \\
$\mathrm{~T}_{4}(80 \%$ pupuk herbal organik $+20 \%$ urea $)$ & 176,0 \\
$\mathrm{~T}_{5}(100 \%$ pupuk herbal organik $+0 \%$ urea $)$ & 161,0 \\
\hline
\end{tabular}


Tabel 2. Jumlah daun tanaman tomat pada berbagai perlakuan substitusi

\begin{tabular}{cc}
\hline \hline Perlakuan & Jumlah Daun \\
\hline $\mathrm{T}_{0}(100 \%$ urea $+0 \%$ pupuk herbal organik $)$ & ---- helai---- \\
$\mathrm{T}_{1}(80 \%$ urea $+20 \%$ pupuk herbal organik $)$ & $201^{\mathrm{abc}}$ \\
$\mathrm{T}_{2}(60 \%$ urea $+40 \%$ pupuk herbal organik $)$ & $157^{\mathrm{a}}$ \\
$\mathrm{T}_{3}(40 \%$ urea $+60 \%$ pupuk herbal organik $)$ & $255^{\mathrm{bc}}$ \\
$\mathrm{T}_{4}(20 \%$ urea $+80 \%$ pupuk herbal organik $)$ & $262^{\mathrm{c}}$ \\
$\mathrm{T}_{5}(0 \%$ urea $+100 \%$ pupuk herbal organik $)$ & $234^{\mathrm{bc}}$ \\
\hline
\end{tabular}

Keterangan: Superskrip yang berbeda pada kolom yang sama menunjukkan perbedaan nyata $(\mathrm{P}<0,05)$

substitusi pupuk anorganik dengan pupuk herbal organik tidak berbeda nyata dibandingkan dengan pemberian semua pupuk urea (kontrol) yang disajikan pada Tabel 2. Kebutuhan unsur hara yang disuplai pupuk anorganik dan pupuk herbal organik dapat menyamai perlakuan kontrol. Pupuk herbal organik akan mengikat unsur hara agar tidak tercuci sehingga tanaman dapat menyerap hara secara maksimal. Menurut Murbandono (2003) menyatakan bahwa bahan organik mampu mengikat unsur hara dan mempertahankan unsur tersebut agar tidak tercuci sehingga akan membuat keadaan unsur hara yang tetap tersedia. Dewi dan Jumini (2012) menambahkan jika unsur hara dalam keseimbangan maka laju pertumbuhan dan kenaikan hasil cenderung meningkat. Jumlah daun yang dihasilkan dari setiap perlakuan sangat berpengaruh terhadap pertumbuhan vegetatif maupun generatif. Daun merupakan organ yang menunjang proses fotosintesis sehingga mampu menghasilkan makanan bagi pertumbuhan tanaman tomat (Sutoyo dan Hulopi, 2009).

Perlakuan substitusi pupuk herbal organik $60 \%$ lebih tinggi dibandingkan dengan substitusi $20 \%$ dan $100 \%$. Hal ini diduga bahwa substitusi pupuk anorganik dengan pupuk organik akan meningkatkan ketersediaan hara sampai substitusi $60 \%$, kemudian turun kembali. Ketersediaan unsur hara yang terkandung dalam pupuk anorganik dan pupuk herbal organik dapat merangsang pembelahan sel sehingga bertambahnya tinggi tanaman dan jumlah daun. Manfaat unsur nitrogen yaitu meningkatkan pertumbuhan tanaman, memproduksi klorofil, dan mempercepat tumbuh daun (Mulyono, 2014). Semakin meningkatnya hara yang diserap oleh tanaman maka proses metabolisme juga akan semakin baik dan selanjutnya akan menghasilkan fotosintat yang lebih banyak (Kartika et al. (2013).

\section{Jumlah Bunga}

Hasil analisis ragam menunjukkan bahwa perlakuan substitusi pupuk anorganik dengan pupuk herbal organik berpengaruh nyata $(\mathrm{P}<0,05)$ terhadap jumlah bunga tanaman tomat. Jumlah bunga pada berbagai perlakuan substitusi pupuk anorganik dengan pupuk herbal organik disajikan pada Tabel 3.

Hasil uji lanjut dengan BNT menunjukkan bahwa jumlah bunga pada semua perlakuan substitusi pupuk organik dengan pupuk herbal organik nyata lebih tinggi dibandingkan dengan pemberian semua (100\%) pupuk urea (kontrol). Pupuk herbal organik disamping mengandung unsur hara nitrogen $(\mathrm{N})$ juga mengandung unsur hara fosfor $(\mathrm{P})$ yang berperan penting dalam asimilasi karbohidrat serta merangsang proses pembungaan. Menurut Sutedjo (2008) bio organik herbafarm juga mengandung mikroba pelarut phospat yang berfungsi untuk pembungaan. Peranan pupuk organik dalam kelarutan fosfor yaitu mengikat unsur $\mathrm{Al}$ dan Fe sehingga fosfor dapat larut. Menurut Adnan et al., (2015) yang menyatakan bahwa unsur $\mathrm{P}$ sering terikat oleh unsur $\mathrm{Al}$ dan $\mathrm{Fe}$ sehingga sulit tersedia di dalam tanah, dengan penambahan pupuk organik maka unsur $\mathrm{P}$ akan tersedia bagi tanaman.

Perlakuan substitusi pupuk herbal organik 
Tabel 3. Jumlah bunga tanaman tomat pada berbagai perlakuan substitusi

\begin{tabular}{cc}
\hline \hline Perlakuan & Jumlah Bunga \\
\hline & --- -bunga---- \\
$\mathrm{T}_{0}(100 \%$ urea $+0 \%$ pupuk herbal organik) & $33,7^{\mathrm{a}}$ \\
$\mathrm{T}_{1}(80 \%$ urea $+20 \%$ pupuk herbal organik) & $62,7^{\mathrm{c}}$ \\
$\mathrm{T}_{2}(60 \%$ urea $+40 \%$ pupuk herbal organik) & $65,0^{\mathrm{c}}$ \\
$\mathrm{T}_{3}(40 \%$ urea $+60 \%$ pupuk herbal organik) & $65,7^{\mathrm{c}}$ \\
$\mathrm{T}_{4}(20 \%$ urea $+80 \%$ pupuk herbal organik) & $52,7^{\mathrm{b}}$ \\
$\mathrm{T}_{5}(0 \%$ urea $+100 \%$ pupuk herbal organik) & $46,3^{\mathrm{b}}$ \\
\hline
\end{tabular}

Keterangan: $\quad$ Superskrip yang berbeda pada kolom yang sama menunjukkan perbedaan nyata $(\mathrm{P}<0,05)$

$20 \%, 40 \%$ dan $60 \%$ lebih tinggi dibandingkan dengan substitusi $80 \%$ dan $100 \%$. Hal ini diduga karena substitusi pupuk organik akan menambah ketersediaan hara $\mathrm{P}$ sehingga akan merangsang pembungaan namun jika kadar bahan organik berlebihan akan meningkatkan kadar kelengasan tanah sehingga dapat memperpanjang fase vegetatif atau cenderung dapat menghambat fase generatif. Menurut Rinasari et al. (2016) menyatakan bahwa pemupukan dengan pupuk organik yang dikombinasikan dengan pupuk anorganik pada perbandingan tertentu dapat meningkatkan kualitas dan kuantitas tanaman. Adanya tambahan unsur fosfor yang terdapat dalam pupuk organik mampu mempercepat pendewasaan tanaman sehingga dengan dosis yang tepat dapat memberikan umur berbunga lebih cepat dan jumlah bunga yang banyak
(Sagala, 2009).

\section{Jumlah Buah}

Hasil analisis ragam menunjukkan bahwa perlakuan substitusi pupuk anorganik dengan pupuk herbal organik berpengaruh nyata $(\mathrm{P}<0,05)$ terhadap jumlah buah tanaman tomat. Hasil pengamatan jumlah buah tomat pada semua perlakuan substitusi pupuk anorganik dengan pupuk herbal organik disajikan pada Tabel 4.

Hasil uji lanjut dengan BNT menunjukkan bahwa jumlah buah pada semua perlakuan substitusi pupuk anorganik dengan pupuk herbal organik nyata lebih tinggi dibandingkan dengan perlakuan pemberian semua pupuk urea (kontrol). Jumlah buah pada substitusi pupuk herbal organik $20 \%, 40 \%, 60 \%$ dan $80 \%$ nyata lebih tinggi dibanding dengan substitusi pupuk herbal organik

Tabel 4. Jumlah buah tanaman tomat pada berbagai perlakuan substitusi

\begin{tabular}{cc}
\hline \hline Perlakuan & Jumlah Buah \\
\hline & --- buah---- \\
$\mathrm{T}_{0}(100 \%$ urea $+0 \%$ pupuk herbal organik $)$ & $4,0^{\mathrm{a}}$ \\
$\mathrm{T}_{1}(80 \%$ urea $+20 \%$ pupuk herbal organik $)$ & $6,7^{\mathrm{c}}$ \\
$\mathrm{T}_{2}(60 \%$ urea $+40 \%$ pupuk herbal organik $)$ & $7,0^{\mathrm{c}}$ \\
$\mathrm{T}_{3}(40 \%$ urea $+60 \%$ pupuk herbal organik $)$ & $7,3^{\mathrm{c}}$ \\
$\mathrm{T}_{4}(20 \%$ urea $+80 \%$ pupuk herbal organik $)$ & $5,7^{\mathrm{bc}}$ \\
$\mathrm{T}_{5}(0 \%$ urea $+100 \%$ pupuk herbal organik $)$ & $5,0^{\mathrm{ab}}$ \\
\hline Keterangan: Superskrip yang berbeda pada kolom yang sama menunjukkan perbedaan nyata $(\mathrm{P}<0,05$
\end{tabular}


$0 \%$ dan $100 \%$. Hal ini diduga karena kombinasi pupuk herbal organik dan pupuk anorganik dapat memenuhi kebutuhan nutrisi tanaman sehingga proses metabolisme akan lebih tinggi dan dapat meningkatkan jumlah daun, jumlah bunga dan jumlah buah. Augustien et al. (2012) mengatakan tersedianya NPK dan kombinasi pupuk organik akan meningkatkan serapan nutrisi bagi tanaman sehingga dapat meningkatan jumlah daun, jumlah bunga, dan jumlah buah tomat. Juhaeti dan Peni (2016) menambahkan pupuk organik mengandung bakteri pelarut fosfat dan bakteri penambat nitrogen yang mampu mengubah materi organik menjadi bentuk anorganik yang tersedia bagi tanaman.

Perlakuan $100 \%$ pupuk herbal organik tidak berbeda nyata dibanding dengan $100 \%$ urea karena penggunaan pupuk herbal organik sebanyak $100 \%$ memiliki ketersediaan unsur hara yang lambat. Pangaribuan et al., (2012) mengatakan bahwa kelemahan pupuk organik adalah unsur hara sangat lambat tersedia sehingga perlu dikombinasikan dengan pupuk anorganik yang menyediakan unsur hara dengan cepat. Pupuk organik granul (POG) merupakan pupuk slow release, yang tidak mudah hancur jika kena air dan tanaman tomat merupakan tanaman semi determinate yang membentuk daun, bunga, dan jumlah buah secara terus menerus sehingga dibutuhkan nutrisi setiap saat walaupun dalam jumlah sedikit (Augustien et al. 2012).

\section{Berat Buah Segar}

Hasil analisis ragam menunjukkan bahwa perlakuan substitusi pupuk herbal organik dan pupuk anorganik berpengaruh nyata $(\mathrm{P}<0,05)$ terhadap berat buah segar tanaman tomat. Hasil pengamatan berat buah tomat perlakuan substitusi pupuk anorganik dengan pupuk herbal organik disajikan pada Tabel 5.

Hasil uji lanjut dengan BNT menunjukkan bahwa berat buah segar tidak semua perlakuan substitusi lebih tinggi dibandingkan pemberian semua pupuk urea (kontrol). Hasil perlakuan substitusi pupuk herbal organik $20 \%, 80 \%$, dan $100 \%$ menunjukkan hasil yang sama dengan kontrol. Hal ini sesuai dengan pendapat Pangaribuan dan Murni (2011) menunjukkan bahwa penggunaan pupuk organik akan mengurangi pemakaian pupuk anorganik sampai setengah dosis tanpa menurunkan produksi buah tomat. Hasil korelasi dengan parameter jumlah daun, bahwa semakin banyak jumlah daun maka semakin meningkat berat buah panen tanaman tomat. Daun merupakan organ tanaman yang berperan dalam proses fotosintesis. Energi matahari yang diterima oleh daun akan dipergunakan dalam reaksi untuk menghasilkan glukosa, karbohidrat dan air yang akan digunakan dalam pertumbuhan dan produksi tanaman (Rehatta et al., 2014).

Substitusi pupuk herbal organik $60 \%$ memiliki berat buah segar tertinggi sebesar 243 gram per tanaman. Keseimbangan pupuk herbal organik dan pupuk anorganik yang tepat dapat mempengaruhi pertumbuhan vegetatif dan bobot buah panen tomat. Unsur hara fosfor dan kalium yang tersedia dalam kedua pupuk saling berkaitan

Tabel 5.Berat buah segar tanaman tomat pada berbagai perlakuan substitusi

\begin{tabular}{cc}
\hline \hline Perlakuan & Berat Buah Segar \\
\hline & --- gram---- \\
$\mathrm{T}_{0}(100 \%$ urea $+0 \%$ pupuk herbal organik $)$ & $140,7^{\mathrm{a}}$ \\
$\mathrm{T}_{1}(80 \%$ urea $+20 \%$ pupuk herbal organik $)$ & $183,5^{\mathrm{ab}}$ \\
$\mathrm{T}_{2}(60 \%$ urea $+40 \%$ pupuk herbal organik $)$ & $196,5^{\mathrm{b}}$ \\
$\mathrm{T}_{3}(40 \%$ urea $+60 \%$ pupuk herbal organik $)$ & $243,0^{\mathrm{c}}$ \\
$\mathrm{T}_{4}(20 \%$ urea $+80 \%$ pupuk herbal organik $)$ & $167,3^{\mathrm{ab}}$ \\
$\mathrm{T}_{5}(0 \%$ urea $+100 \%$ pupuk herbal organik $)$ & $156,3^{\text {ab }}$ \\
\hline
\end{tabular}

Keterangan: $\quad$ Superskrip yang berbeda pada kolom yang sama menunjukkan perbedaan nyata $(\mathrm{P}<0,05)$ 
sehingga unsur-unsur tersebut diserap oleh tanaman dan berfungsi mengaktifkan enzim yang berperan dalam metabolisme yang digunakan untuk fotosintesis dan hasilnya berupa fotosintat. Hal ini sesuai dengan pendapat Irshad (2011) yang menyatakan bahwa pemberian pupuk anorganik yang dikombinasikan dengan pupuk organik menyebabkan hasil buah tomat lebih baik dibanding jika diberikan tunggal.

\section{KESIMPULAN}

Hasil penelitian dapat disimpulkan bahwa substitusi pupuk anorganik dengan pupuk herbal organik dapat meningkatkan pertumbuhan dan produksi pada parameter jumlah daun, jumlah bunga, jumlah buah dan berat buah segar. Substitusi pupuk herbal organik terbaik adalah pada perlakuan anorganik $40 \%$ dan substitusi pupuk herbal organik $60 \%$.

\section{DAFTAR PUSTAKA}

Adnan, I. S., B. Utoyo, dan A. Kusumastuti. 2015. Pengaruh NPK dan pupuk organik terhadap pertumbuhan bibit kelapa sawit (Elaeis guineensis Jacq.) di Main Nursery. Jurnal Agro Industri Perkebunan 3(2) : 69-81.

Agustina, L, 2004. Dasar Nutrisi Tanaman. Rineka Cipta. Jakarta.

Augustien, N., W. Mindari, Maroeto, dan H. Suhardjono. 2012. Efek kombinasi pupuk organik (serbuk dan granul) dan pupuk anorganik pada entisols untuk tanaman cabai dan tomat. Prosiding Seminar Nasional LPPM UPN "Veteran" Jatim.

Bernadus, T. dan W. Wahyu. 2002. Bertanam Tomat. Agromedia Pustaka. Jakarta.

Dewi, P. Dan Jumini. 2012. Pertumbuhan dan Hasil Dua Varietas Tomat Akibat Perlakuan Jenis Pupuk. Jurnal Floratek 7 : 76-84.

Haerul, Muammar, dan J. L. Isnaini. 2015. Pertumbuhan dan produksi tanaman tomat (Solanum lycopersicum L.) terhadap POC (Pupuk Organik Cair). J. Agrotan 1(2) :
$69-80$

Hayani, Rizki, dan Novi. 2013. Efektivitas pupuk bio organik terhadap produksi tanaman semangka (Citrullus vulgaris L.) di Desa Sungai Tunu Barat Kecamatan Ranah Pesisir Kabupaten Pesisir Selatan. Laporan Penelitian Program Studi Pendidikan Biologi STKIP PGRI. Sumatera Barat.

Heriani, N., W. A. Zakaria, dan A. Soelaiman. 2013. Analisis keuntungan dan risiko usahatani tomat di Kecamatan Sumberejo Kabupaten Tanggamus. JIIA 1 (2) : 169173.

Irshad A.H. 2011. Effect of Organic Manures and Inorganic Fertilizers on Biochemical Constituents of Tomato (Lycopersicon esculentum). Advances in Environmental Biology, 5(4): 683-685.

Juhaeti, T dan L. Peni. 2016. Pertumbuhan, produksi dan potensi gizi terong asal enggano pada berbagai kombinasi perlakuan pemupukan. Berita Biologi 15(3) : 303-313.

Kartika, E., Z. Gani, dan D. Kurniawan. 2013. Tanggapan tanaman tomat (Lycopersicum esculentum. Mill) terhadap pemberian kombinasi pupuk organik dan pupuk anorganik. Fakultas Pertanian Universitas Jember. Vol 2 (3) : 122-131.

Leovini, H. 2012. Pemanfaatan pupuk organik cair pada budidaya tanaman tomat (Solanum lycopersicum L.). Makalah Seminar Umum Program Studi Agronomi Universitas Gadjah Mada. Yogyakarta.

Murbandono, L. 2003. Membuat Kompos. Penebar Swadaya. Jakarta.

Mulyono. 2014. Membuat MOL dan Kompos dari Sampah Rumah Tangga. Jakarta: PT AgroMedia Pustaka.

Nasrun, A., Rover, dan Mashadi. 2014. Uji 
beberapa varietas dan pemberian pupuk bio organik herbafarm terhadap pertumbuhan dan produksi jagung manis (Zea mays saccharata. Sturt). JGS vol. $3: 85-92$.

Pangaribuan, D. H. dan A. M. Murni. 2011. Pertumbuhan dan produksi tomat pada aplikasi aneka kompos kotoran ternak. Prosiding Seminar Nasional PEHORTI. Jurusan Budidaya Pertanian, Universitas Lampung, Bandar Lampung.

Pangaribuan, D. H., M. Yasir, dan N. K. Utami. 2012. Dampak bokashi kotoran ternak dalam pengurangan pemakaian pupuk anorganik pada budidaya tanaman tomat. J. Agron. Indonesia 40 (3) : 204-210.

Rehatta, H., A. Mahulete, dan A. M. Pelu. 2014. Pengaruh Konsentrasi Pupuk Organik Cair Bioliz dan Pemangkasan Tunas Air / Wiwilan terhadap Pertumbuhan dan Produksi Tanaman Tomat (Lycopersicon esculentum Miller). Jurnal Budidaya Pertanian 10 (2) : 88-92.

Rinasari, S. P. O., Z. Kadir, dan Oktafiri. 2016. Pengaruh Konsentrasi Pupuk Organonitrofos terhadap Pertumbuhan dan Produksi Tanaman Tomat (Lycopersicon esculentum Mill.) secara Organik dengan Sistem Irigasi Bawah Permukaan (Sub Surface Irrigation. Jurnal Teknik Pertanian Lampung 4 (4) : 325-234.

Sagala, A. 2009. Respon pertumbuhan dan produksi tomat (Solanum lycopersicum Mill.) dengan pemberian unsur hara makromikro dan blotong. Skripsi Departemen Budidaya Pertanian Universitas Sumatera Utara. Medan.

Subhan, N. Kartika, dan N. Gunadi. 2009. Respons tanaman tomat terhadap penggunaan pupuk majemuk NPK 15-15-15 pada tanah latosol pada musim kemarau. J. Hort. 19 (1) : 40-48.

Sutedjo. 2008. Pupuk dan cara pemupukan. PT. Rinika Cipta. Jakarta.

Sutoyo dan F. Hulopi. 2009. Pengaruh pupuk organik supernasa pada berbagai dosis dan frekwensi terhadap pertumbuhan dan hasil tanaman tomat. Buana Sains 9 (2) : 153158.

Syaifuddin, Dahlan, dan Buhaerah. 2013. Pengaruh Urea terhadap Produksi Tanaman Tomat. Jurnal Agrisistem 9 (1) : 1858-4330.

Syofia, I., Alridiwirsah, dan A. S. Pohan. 2015. Respon beberapa varietas dan pemberian pupuk bio organik terhadap pertumbuhan dan produksi semangka. J. Agrium 19 (3) : 229-237.

Wahyunindyawati, F. Kasijadi, dan Abu. 2012. Pengaruh pemberian puuk organik "Biogreen Granul" terhadap pertumbuhan dan hasil tanaman bawang merah. Journal Basic Science and Technology $1: 21-25$. 